\title{
Composite BME-AuNPs: Chemopreventive effect on skin carcinoma and Inhibition on leukemia blood cancer Cells
}

\author{
Ramesh Gunti ${ }^{1}$, Gangappa Dharmapuri ${ }^{2}$, Sumanjoshi Doddapaneni ${ }^{3}$, Chander Amgoth ${ }^{4}$ \\ ${ }^{1}$ Departmentof Pharmacology, K. L. E. S College of Pharmacy, Hubli, Karnataka, 580 031, India \\ ${ }^{2}$ Deparment of Animal Biology, School of life Sciences, University of Hyderabad, 500 046, India \\ ${ }^{3}$ Deparment of Biochemistry, Acharya Nagarjuna University, Andhra Pradesh, 522 510, India \\ ${ }^{4}$ School of Engineering Sciences and Technology, University of Hyderabad, Hyderabad, 500 046, India \\ *Corresponding author: Tel:(+91) 9908812120; E-mail: chander@uohyd.ac.in
}

Received: 27 March 2017, Revised: 01 April 2017 and Accepted: 09 April 2017

DOI: $10.5185 /$ amlett.2017.1733

www.vbripress.com/aml

\begin{abstract}
Herein, the chemopreventive effect of oral and topical administration of composite of alcoholic plant extracts of Butea monosperma (Lam.) Taub. (BME) leaves and gold nanoparticles (Au NPs) have been investigated. The tumor growth has been initiated by the 7,12-dimethyl benz (a) anthracene (DMBA) and skin tumorigenesis in male Swiss albino mice were promoted by the 12-O-tetradecanoylphorbol-13-acetate (TPA). However, malignant feature of the skin tumors were treated with composite of (BME-Au NPs) to reduce the tumor incidence, tumor burden, tumor yield, cumulative number of tumors, tumor size, mass, and volume, respectively. Furthermore, studies were extended to treat CML (chronic myeloid leukemia) K562 (blood cancer) cells with the combination of DMBA/TPA-(BME-Au NPs) and it show greater $(\sim 80 \%)$ cellular inhibition on cancer cells. Compare to BME alone the composite of (BME-Au NPs) shows significant effect on skin carcinoma and as well on cancer cells. Copyright @ 2017 VBRI Press.
\end{abstract}

Keywords: Chemopreventive, plant extract, composite, cell inhibition, skin carcinoma.

\section{Introduction}

Cancer is a disease characterized by uncontrolled proliferation of cells that have transformed from the normal cells of the body [1]. The cancer cells can invade the adjacent cells and metastasize to distant tissues. The international union against cancer has defined cancer as a disturbance of growth which is characterized by excessive proliferation of cells without apparent relation to physiological demands of organs involved [2]. All cancer is multifactorial in origin; they include genetics, hormonal, metabolic, physical, chemical and environmental factors. The human population is exposed to a number of chemical mutagens and carcinogens accidentally, occupationally or by lifestyle habits. The skin is the major environmental interface for the body and, as a consequence of its direct exposure to variety of xenobiotics, [3] is at a uniquely high risk of developing cancer. Non-melanoma skin cancers (NMSCs), usually basal cell and squamous cell cancers are the most common types of skin cancer. Incidence of NMSCs has been increasing worldwide at an alarming rate. Skin cancer became one of the most important issues globally. Several methods such as chemotherapy, radiotherapy and surgery are related to cancer treatment. However, they are associated with several adverse effects such as alopecia, nausea, vomiting and general weakening of the body immune system due to bone marrow suppression and significantly increase patient risk for infection. Different types of plants have been used traditionally as a source of medicine for all types of diseases. Medicines derived from plants have played a pivotal role in health care of ancient and modern cultures. Numerous scientific reports validate the traditional uses of Butea monosperma [4-5]. It has been reported to possess antioxidant activity, cytotoxic activity and also preventive effect on hepatic carcinogenesis. As per the, Lau GT et al. reports, the Butein is rich with flavanoids isolated from the flowers of Butea monosperma which down regulates phorbol-12myristate-13-acetate-induced $\mathrm{COX}-2$ transcriptional activity in cancerous and non-cancerous breast cells. Sehrawat et al. have reported that flowers of Butea monosperma exhibited chemopreventive effect against thioacetamide-mediated tumor promotion related hepatic alterations in wistar rat (A rat of a strain developed for 
laboratory purposes).Further, it has been reported that aqueous extract of Butea monosperma flowers exhibited a strong anticancer activity (growth inhibition, cell cycle arrest, [6] pro-apoptotic activity and interference with mitogenic signaling) in hepatoma cells and shows minimal cytotoxic effect on non-transformed AML12 hepatocytes. However, the effect of Butea monosperma alone on chemical induced skin carcinoma shows minimal effect but the composite of (BME-Au NPs) shows significant effect. Hence, in the present work we aimed to investigate the effect of composite of alcoholic extract of Butea monosperma (Lam.) Taub. Leaves with Au NPs on DMBA/TPA induced skin carcinoma in mice and direct cellular treatment for K562 leukemia blood cancer cells [7-9].

\section{Experimental Section}

\section{Materials}

All the chemicals required for the experiments were purchased with high purity and used without further purification. The 7, 12-diemthylbenz[a]anthracene (DMBA) and 12-O-tetradecanolyphorbol-13-acetate (TPA) were purchased from sigma Aldrich. The chemicals, thiobarbituric acid and diphenyl amines were obtained from SD Fine chemicals. All other chemicals and solvents were used with the analytical grade.

\section{Animals}

Healthy adult male Swiss albino mice weighing 25-30 g was obtained from the Institutional Animal House of the H. S. Kottambari Science Institute, Vidyanagar, Hubli, and Karnataka, India. They were housed in well ventilated cage and $12 \mathrm{~h}$ with day and night cycle and temperature maintained between $23 \pm 1{ }^{\circ} \mathrm{C}$. The animals were allowed free access to standard laboratory pellet diet and drinking water ad-libitum. These mice were used for the tumor based measurements and chemoprevention in skin carcinoma cells.

\section{Collection of leaves}

The fresh leaves of Butea monosperma (Lam.) Taub. were collected from local area in Vidyanagar, Hubli, karmataka, India. These leaves were identified and authenticated by Dr. B.D. Huddar, Head of the Department of Botany, Sri Kadasiddeshwar, Arts College and H.S. Kottambari Science Institute, Vidyanagar, Hubli. Leaves were washed thoroughly under running tap water to remove dirt and allowed to dry at $\sim 30-45^{\circ} \mathrm{C}$ for $24 \mathrm{~h}$.

\section{Extraction of BME and composite of (BME-Au NPs)}

The well dried leaves of BME were used to prepare powder by using agate mortar. Then, amount of $500 \mathrm{~g}$ of BME powder was extracted with $95 \%$ ethanol fallowed by using soxhlet extract apparatus. The extract was filtered with whatmann filter paper and concentrated at low temperature to give the solid mass of EtOH extract which is equal to $66 \mathrm{~g}$. The yield of the final compound is ca. $13.2 \%(\mathrm{w} / \mathrm{w})$. Finally, the extract was preserved in a closed container and stored in desiccators.

\section{Preparation of composite of (BME-Au NPs)}

The well dried BME extract $5 \mathrm{~g}$ was separated from sample vial which is stored in desiccators and dispersed in $10 \mathrm{~mL}$ of ethanol and used to prepare the composite of (BME-Au NPs). The $\sim 200 \mu \mathrm{g}$ of gold nanoparticles (Au NPs), [10-11] dispersed in DI water was mixed with BME extract and composite preparation fallowed by the sonication for $4 \mathrm{~min}$ at room temperature. The mixture of $\mathrm{BME}$ and Au NPs were dried at reduced pressure by using rotary evaporator and used to prepare the samples for SEM, TEM, EDAX and other microscopic characterizations.

\section{Treatment and statistical calculations}

Adult male Swiss albino mice ( 25-30 g) were divided into four different groups of ten in each (two groups were normal and carcinogen control and another two groups were treated with BME-Au NPs). In normal group, mice received $100 \mu \mathrm{L} /$ mouse acetone topically twice in a week for 15 weeks. In carcinogen control, mice received DMBA $(0.24 \%) 200 \mu \mathrm{L} /$ mouse topically. In first week, $5 \mathrm{nM}$ TPA $50 \mu \mathrm{L} /$ mouse twice in a week, from second week up to 15 weeks in treated groups, mice received DMBA/TPA-(BME-Au NPs) $\sim 300 \mathrm{mg} / \mathrm{kg}$ b.w. orally and topically. At the end of study mean survival time, change in body weight analysis, cumulative number of tumors, tumor incidence, tumor burden, tumor yield, average latent period, tumor size, volume, mass, and lipid peroxides, total protein levels in plasma and DNA content in skin tissue homogenate, [12-13] and histopathological changes, [14] in the skin were studied and reported in fallowing sections.

\section{Results and discussion}

Results demonstrate the oral and topical administration of the composite of (BME-Au NPs) shows significant reduction in tumor incidence, tumor burden, and tumor yield. The composite has been seen in TEM images (Fig. 1).

The cumulative number of tumors, tumor size, shape, mass, volume, and LPO levels with a significant increase in the average latent period of tumor appearance has been reported. The TEM image (Fig. 2) illustrates the morphology and size of pure Au NPs. The total protein and DNA content has been measured. The dose selection and In-vivo chemopreventive effect, [15-19] of (BME-Au NPs) was chosen based on $\mathrm{LD}_{50}$ values. However, 300 $\mathrm{mg} / \mathrm{kg}$ b.w. dose was selected and suspension was prepared in $20 \%$ tween-20 in normal saline. The chemopreventive property of (BME-Au NPs) was determined using DMBA/TPA induced two stage carcinogenesis models in mice. The induction of 
experimental tumor in mice received a topical application of the carcinogen 7, 12- dimethylbenz [a] anthracene (DMBA) $200 \mu \mathrm{L} /$ mouse; Twice a week to the dorsal skin. This is accomplished by holding the mouse by the tail and allowing it to hold onto the wire top of an empty mouse cage. Upon treatment, the mice were placed in cages where they remain for 7-day observation. After one week, the bedding was discarded in the infectious waste. The SEM image (Fig. 3) corroborates the morphology of BME-Au NPs composite which used for oral and topical administration for skin carcinoma and cellular inhibition and size of the gold nanoparticles is very small ( 20-50 $\mathrm{nm}$ ) which cannot be seen in SEM images.
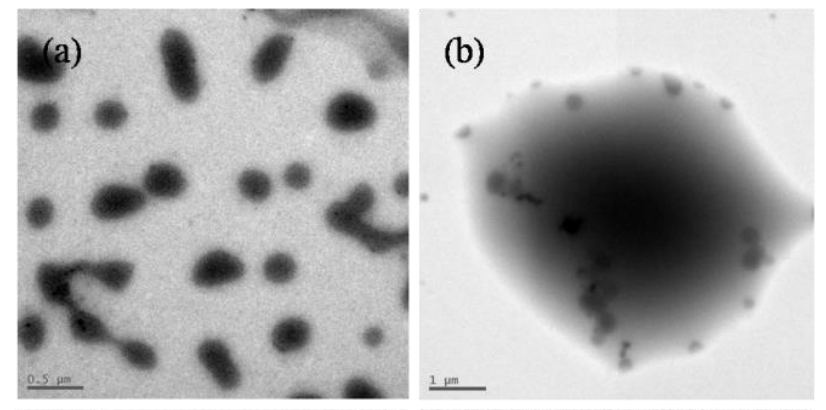

(c)
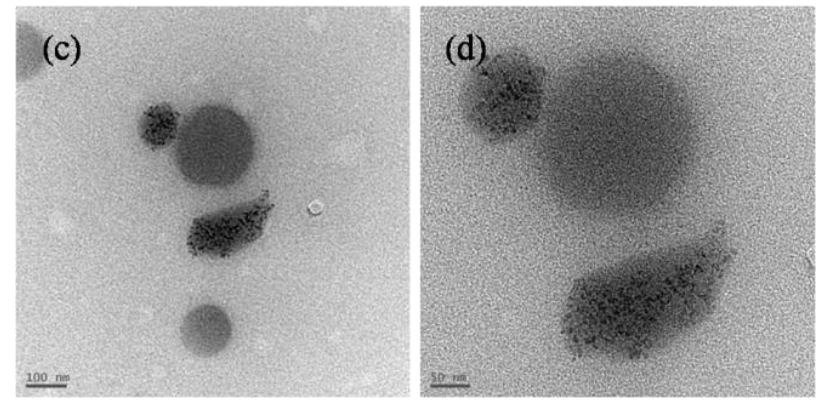

Fig. 1. TEM images illustrate the morphology of BME plant extract and it's composite with gold nanoparticles. Image (a) corresponds to only plant extract without any gold nanoparticles, (b) for BME plant extract embedded with gold nanoparticles, (c and d) shows the composite from lower to higher magnifications.
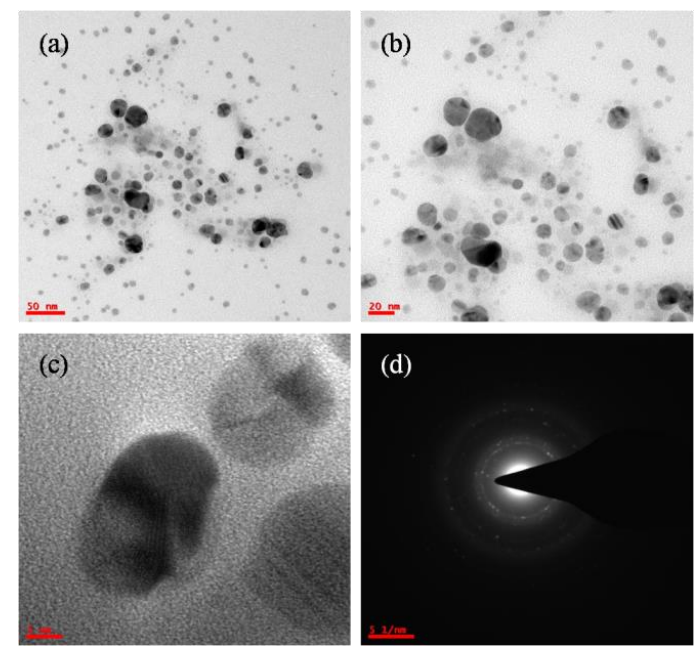

Fig. 2. TEM images (a, b) represents the morphology (size, shape) of gold nanoparticles from lower to higher magnifications. The image (c) corresponds to HRTEM for gold nanoparticles with lattice parameter and (d) shows the diffraction pattern for gold nanoparticles.
Although DMBA is a carcinogen, this initiating dose does not cause skin tumors in the mice. Tumor development requires subsequent repetitive treatment with a tumor promoter. Hence, one week after carcinogen exposure, the mice received twice weekly treatments with the tumor promoter 12-O-tetradecanolyphorbol-13-acetate (TPA $\sim 50 \mu \mathrm{L} /$ mouse). Although TPA is a strong mouse skin irritant and a tumor promoter of carcinogen treated skin, it is not a tumor promoter for human skin; human cells are not responsive to it. Skin tumors were counted once in a week for 15 weeks. However, Table S3, (supporting information) shows the group-III and IV represents the treatment process with test compound (BME-Au NPs) one week before the induction of tumor and continued for thrice in a week up to 15 -week $1 \mathrm{~h}$ before the application of DMBA/TPA chemicals. The collection of blood and organs, tissue homogenate was followed by the anaesthetization of mice by using diethyl ether (Et-O-Et) after 15-week treatment and observations. The blood samples were collected by retro-orbital puncture in sterilized, heparinized tubes. The plasma was separated and used for lipid peroxides, and total protein estimation. The mice were killed by cervical dislocation and the dorsal skin was excised out for histopathological studies and for DNA estimation.
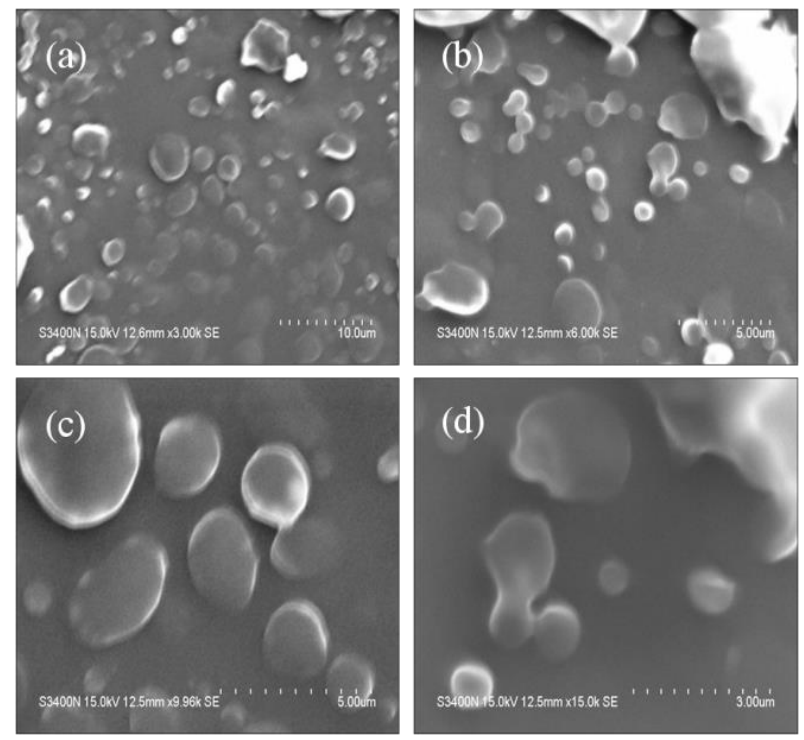

Fig. 3. SEM images for composite of BME plant extract embedded with Au NPs.

The liver and spleen were excised immediately and weighed. At the end of experiment, animals were sacrificed by cervical dislocation, tumor affected dorsal skin was quickly removed and thoroughly washed with chilled PBS solution (phosphate buffer saline), $0.85 \%$, whose $\mathrm{pH}$ is $\sim 7.4$ with $0.01 \mathrm{mmol}$ concentration. Then, it was blotted for dry and weighed. A $10 \%(\mathrm{w} / \mathrm{v})$ tissue homogenate was prepared in $0.15 \mathrm{M}$, Tris $\mathrm{HCl}$ ( $\mathrm{pH}$ 7.4) [20]. The tumor incidence, tumor burden, tumor yield, decrease in the average latent period, increase in the tumor size, mass, and volume and decrease in the survival time and body weight, increase in the liver 
and spleen weight, decreased levels of total protein in plasma, and decrease in DNA content of the skin tissue homogenate has been calculated through the formulas produced in the Table S1, (supporting information). The cumulative number of tumors and its formation time (in weeks) has been reported in Fig. S2, (supporting information).
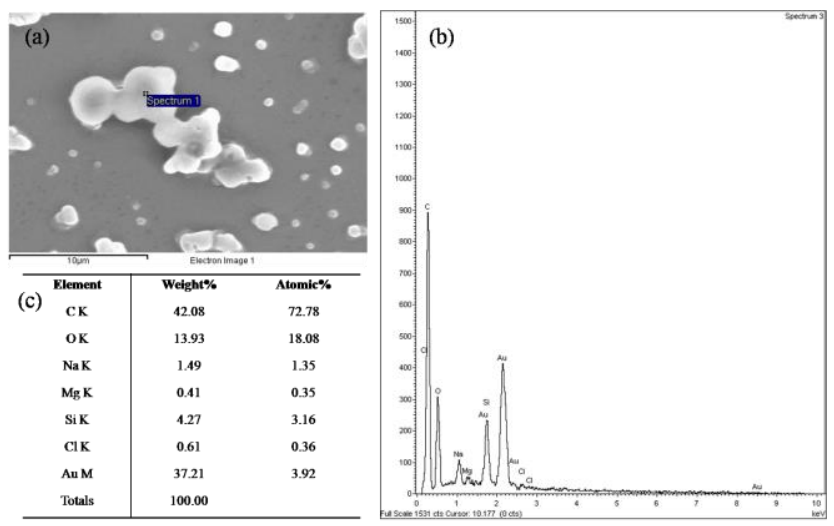

Fig. 4. EDAX to analyze the elemental composition present in the composite of BME plant extract embedded with Au NPs. The SEM image (a) shows the morphology of composite, (b) shows the peak intensities for the elements present in the composite and table (c) corroborates the amount of weight (\%) and atomic (\%) present in the composite.

\section{DNA content estimation}

The DNA content was estimated by the Burton method. Tissue homogenate was prepared as mentioned previously and centrifuged at $10000 \mathrm{RPM}$ for $10 \mathrm{~min}$ and washed with $5 \mathrm{~mL}$ cold $10 \%$ TCA. Thereafter, the homogenate was kept for $30 \mathrm{~min}$ at $\sim 4^{\circ} \mathrm{C}$ and centrifuged at 10000 RPM for $10 \mathrm{~min}$. The pellet was collected and mixed with $5 \mathrm{~mL}$ cold $10 \%$ TCA. Then, the mixture was centrifuged at $10000 \mathrm{RPM}$ for $10 \mathrm{~min}$ and further mixed with $5 \mathrm{~mL}$ alcohol ether (3:1) and centrifuged at 10000 RPM for $10 \mathrm{~min}$. The pellet was collected and mixed with $5 \mathrm{~mL} 1 \mathrm{~N}$ $\mathrm{KOH}$ and incubated for $18 \mathrm{~h}$ at $\sim 37^{\circ} \mathrm{C}$. The solution was mixed with $0.4 \mathrm{~mL}$ of $6 \mathrm{~N} \mathrm{HCl}$ and $5 \mathrm{~mL}$ of cold $5 \%$ TCA and allowed to precipitate at $\sim 4^{\circ} \mathrm{C}$ for $30 \mathrm{~min}$. Again, it was centrifuged at $10000 \mathrm{RPM}$ for $10 \mathrm{~min}$. The pellet was collected and mixed with $5 \mathrm{~mL} 5 \%$ TCA, heated for $15 \mathrm{~min}$ at $\sim 90^{\circ} \mathrm{C}$ and cooled under tap water. Again, it was centrifuged at $10000 \mathrm{RPM}$ for $10 \mathrm{~min}$ and supernatant was collected. Then, $1 \mathrm{~mL}$ of supernatant was mixed with $2 \mathrm{~mL}$ of diphenyl reagent (diphenylamine: GAA: conc. $\left.\mathrm{H}_{2} \mathrm{SO}_{4}, 1: 100: 2.5\right)$ and again incubated for $18 \mathrm{~h}$ at $\sim 37^{\circ} \mathrm{C}$. The absorbance was recorded at $\sim 620 \mathrm{~nm}$. The levels of DNA content estimated was expressed as $\mathrm{mg} / \mathrm{g}$ of tissue sample and values were reported in the Table S13, (supporting information). The DNA content (mean \pm SEM) for control samples is $0.8670 \pm 0.07443$, for DMBA/TPA treated samples $0.3166 \pm 0.08737$, oral (BME-Au NPs) treated sample $1.201 \pm 0.1557$ and for topical (BME-Au NPs) treated samples it ranges from $0.6970 \pm 0.1624$, respectively.

\section{The lipid peroxide level in plasma}

The LPLP was analyzed by the TBARS (2-thiobarbituric acid reactive substances) method. The blood was drawn from each mouse in the conventional way and plasma was separated by centrifugation at 2000 RPM for 20 minutes. The determination of TBARS through the malonaldehyde (MDA) as an index of lipid peroxidation, [21-22] was carried out according to the Niehaus $W G$ method. The main principle involved in this is, free oxygen causes breakdown of poly unsaturated free fatty acid in biomembranes and the end product formed is MDA. This end product has high affinity to form complex with thiobarbituric acid. The proposed method is based on the formation of purple colored product by the reaction of MDA with TBA in an acidic medium upon heating at $\sim 80{ }^{\circ} \mathrm{C}$. A molecule of MDA forms complex with two molecules of TBA to give colored product which is measured calorimetrically at $\sim 532 \mathrm{~nm}$ (excitation). The amount of MDA was calculated using following formula (7) in Table S1, (supporting information). It expresses the MDA (in nmol) and protein (in $\mathrm{mg} / \mathrm{mL}$ ) using molar extinction co-efficient of $1.56 \times 10^{5} \mathrm{~m}^{-1} \mathrm{~cm}^{-1}$. The Table S11, (supporting information) shows the difference between LPLP (mean \pm SEM) for control samples is $2.596 \pm 0.6018$, for DMBA/TPA treated samples $8.368 \pm 1.885$, oral (BME-Au NPs) treated sample $4.642 \pm 0.3099$ and topical (BME-Au NPs) treated samples it ranges from $4.070 \pm 0.5445$, respectively. Similarly, the total protein content (TPC) in plasma was determined by modified Biuret end point assay using span diagnostic kit. The assay principle for the peptide bond of protein reacts with cupric ion in alkaline solution to form a colored chelate. The absorbance of each sample was measured at excitation wavelength of $\sim 578 \mathrm{~nm}$. The biuret reagent contains sodium potassium tartarate which helps in maintaining solubility of this complex at alkaline $\mathrm{pH}$ medium. The absorbance of the final color is proportional to the concentration of total protein in the sample. The reagents and sample were mixed well and incubated at $\sim 37{ }^{\circ} \mathrm{C}$ for $5 \mathrm{~min}$ in $\mathrm{CO}_{2}$ incubator. The program analyzer has been set as per the above assay parameter.

Table. 1. Data interprets the weight of liver and spleen in mice for four samples (control, DMBA/TPA, DMBA/TPA/BME (oral) and DMBA/TPA/BME (topical)).

\begin{tabular}{|c|c|c|c|c|c|c|c|c|}
\hline \multicolumn{9}{|c|}{ Liver weight (g) and Spleen weight (mg) } \\
\hline \multirow[t]{2}{*}{ S. No } & \multicolumn{2}{|c|}{ Control } & \multicolumn{2}{|c|}{ DMBA/TPA } & \multicolumn{2}{|c|}{$\begin{array}{c}\text { DMBA/TPA-(BME-Au NPs) } \\
\text { (Oral) } \\
\end{array}$} & \multicolumn{2}{|c|}{$\begin{array}{c}\text { DMBA/TPA-(BME-Au NPs) } \\
\text { (Topical) }\end{array}$} \\
\hline & Liver & Spleen & Liver & Spleen & Liver & Spleen & Liver & Spleen \\
\hline 1 & 1.45 & 180 & 2.61 & 180 & 1.26 & 100 & 1.29 & 120 \\
\hline 2 & 1.73 & 120 & 2.52 & 180 & 1.5 & 80 & 3.39 & 140 \\
\hline 3 & 1.51 & 178 & 2.13 & 290 & 1.35 & 120 & 1.06 & 150 \\
\hline 4 & 2.05 & 120 & 1.75 & 292 & 1.62 & 37.8 & 1.42 & 190 \\
\hline 5 & 1.52 & 100 & 1.51 & 142.6 & 1.40 & 72.2 & 0.98 & 110 \\
\hline 6 & 1.64 & 167.2 & 2.19 & 247.4 & 1.24 & 98.5 & 1.16 & 150 \\
\hline 7 & 1.55 & 140 & 4.64 & 285 & 1.28 & 75.2 & 1.12 & 68.6 \\
\hline Mean & 1.636 & 143.6 & $2.48^{*}$ & $231.1^{*}$ & 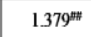 & $83.39^{m+m+1}$ & $1.489^{\#}$ & $132.7^{\text {thH }}$ \\
\hline \pm SEM & 0.0773 & 12.04 & 0.3898 & $\begin{array}{c}* \\
23.63\end{array}$ & 0.5284 & 9.912 & 0.3215 & 14.41 \\
\hline
\end{tabular}


The estimation of TPC was carried out according to the fallowing formula (8) in Table S1, (supporting information) and it has been calculated as per the Table S12, (supporting information) and values reported as mean \pm SEM for control sample is $8.663 \pm 0.4452$, for DMBA/TPA treated samples $6.887 \pm 0.4052$, oral (BME-Au NPs) treated sample 9.267 \pm 0.5287 and topical (BME-Au NPs) treated samples it ranges from $8.169 \pm 0.5261$, respectively.

\section{Statistical analysis}

The data are expressed as Mean \pm SEM (standard error of measurement) and analyzed using One Way ANOVA followed by Student's ' $\mathrm{t}$ ' test, $\mathrm{p}<0.05$ is considered as significant. However, two stage carcinogenesis models were used to study the chemopreventive effect of composite of (BME-Au NPs) using DMBA as an initiator and TPA as a promoter. The topical application of DMBA followed by TPA results in skin tumorigenesis as indicated by increase in the tumor incidence, tumor burden, tumor yield, and cumulative number of tumors, decrease in the average latent period, increase in the tumor size, mass, and volume. The decrease in mean survival time for control, DMBA/TPA, oral and topical samples from $105 \pm 0.0,77.70 \pm 13.90,86.80 \pm 12.13$, and $88.20 \pm 11.25$ has been incorporated in Table S4, (supporting information). The initial and final body weights have been represented in the Table S5, (supporting information). The weight difference in liver and spleen has been reported in the Table 2 . The decreased levels of TPC in plasma, and DNA content of the skin tissue homogenate associated with increase in oxidative stress as indicated by increased levels of lipid peroxides in plasma. The treatment with (BME-Au NPs) at $300 \mathrm{mg} / \mathrm{kg} \mathrm{b.w.,} \mathrm{orally} \mathrm{and} \mathrm{topically} \mathrm{prevented} \mathrm{the}$ DMBA/TPA induced as indicated by decrease in the tumor incidence, burden $0.0 \pm 0.0$ for control,8.857 \pm 3.508 for DMBA/TPA, $0.5714 \pm 0.3689$ for oral and $2.143 \pm 0.7693$ for topical treatment. The Table S6, (supporting information), shows the Effect of BME-Au NPs on tumor burden in mice exposed to DMBA/TPA topical application. The Table S7, (supporting information), shows the effect of BMEAu NPs on tumor yield in mice exposed to DMBA/TPA topical application. The data are expressed as Mean \pm SEM $(n=10)$. The ${ }^{*} p<0.05$ for DMBA/TPA, ${ }^{\#} p<0.05$ topical treated samples. The increase in the average latent period has been reported in the Table S8, (supporting information), effect of BME-Au NPs on average latency period in mice exposed to DMBA/TPA topical application. The data are expressed as Mean \pm SEM $(\mathrm{n}=14)$. The ${ }^{* * *} \mathrm{p}<0.001$ for DMBA/TPA, ${ }^{\#} \mathrm{p}<0.01$ for oral and ${ }^{*} \mathrm{p}<0.05$ for topical treated samples. The decrease in the tumor size (Table S9, supporting information), increase in mean survival time (Table $\mathbf{S 4}$, supporting information), body weight (Table S5, supporting information) and decrease in the liver and spleen weight (Table 1). The (Table 1) shows the weight of liver and spleen decreased in (BME-Au NPs) treated samples (oral and topical) compared to control samples. The increased levels of total protein in plasma, and increase in DNA content of the skin tissue homogenate and it is associated with decreased oxidative stress as indicated by decreased levels of lipid peroxides in plasma (Table S11, supporting information). The survival time in the animals after treatment with BME-Au NPs increased when compared to DMBA/TPA treated animals. Thus, it clearly suggests the increase in the lifespan of animals with the treatment of BME-Au NPs.

Table. 2. Depict the tumor volume initiated with DMBA/TPA and suppressed with composite of (BME-Au NPs) through the oral and topical administration.

\begin{tabular}{|c|c|c|c|c|}
\hline \multicolumn{5}{|c|}{ Tumor volume per mouse (mm ${ }^{3}$ ) } \\
\hline S. NO & Control & DMBA/TPA & $\begin{array}{c}\text { DMBATPA-(BME-Au NPs) } \\
(\text { Oral) }\end{array}$ & $\begin{array}{c}\text { DMBATPA-(BME-Au NPs) } \\
\text { (Topical) }\end{array}$ \\
\hline 1 & 0 & 20.398 & 9.654 & 3.902 \\
\hline 2 & 0 & 10.605 & 4.291 & 5.370 \\
\hline 3 & 0 & 13.595 & 0 & 7.595 \\
\hline 4 & 0 & 9.514 & 0 & 6.246 \\
\hline 5 & 0 & 12.681 & 0 & 4.414 \\
\hline 6 & 0 & 8.801 & 0 & 0 \\
\hline 7 & 0 & 7.206 & 0 & 0 \\
\hline 8 & 0 & - & - & - \\
\hline 9 & 0 & - & - & - \\
\hline 10 & 0 & - & - & $3.441 \pm 1.082^{* \# \#}$ \\
\hline Mean \pm & $0.0 \pm 0.0$ & $11.83 \pm$ & $1.992 \pm 1.413^{\# \#}$ & \\
\hline SEM & & $1.652^{* * *}$ & & 0 \\
\hline
\end{tabular}

However, the supplementation of composite of BME$\mathrm{Au}$ NPs orally and topically to DMBA/TPA treated mice did not prevent decreased body weight. The weight of liver of mice in DMBA/TPA treated group was significantly increased. Since liver is the site for biotransformation of xenobiotics (including carcinogens) and detoxification process, the phase-I and phase-II detoxification agents plays a crucial role in the alterations of liver. The increased weight of liver is because of increase in the level of phase-I detoxification agents and decrease in the activities of phase-II detoxification agents in the liver of skin tumor bearing animals. The weight of spleen of mice in DMBA/TPA treated group was significantly increased, this effect has been shown with severe splenomegaly in skin tumor bearing animals. The increased weight of liver and spleen were significantly reduced with the administration of BME-Au NPs orally and topically. Thus, it clearly suggests the chemopreventive effect of composite of BME-Au NPs. Average latent period (the lag between the application of the promoting agent and the appearance of $50 \%$ of tumors) was significantly less in animals which were exposed to DMBA/TPA, whereas in BME treated animals orally and topically increase the average latent period, indicating the delaying effect of BME-Au NPs on the promotion phase of carcinogenesis. Moreover, DMBA is metabolized to dihydrodiol epoxide which is the ultimate carcinogen, mediated carcinogenic process by inducing 
chronic inflammation over production of ROS and oxidative DNA damage. In DMBA/TPA treated animals the histology of skin section showed marked acanthosis (diffused epidermal dysplasia) with irregular proliferation and deposition of keratinocyte pearls were observed in dermis and epidermis which is characteristic feature of well differentiated squamous cell carcinoma, dermal fibrosis, decreased hair follicles and sebaceous glands, disrupted basal lamina, hyperkeratosis i.e. thickening of keratinized layer over the epidermis were observed. Along with these changes severe dysplastic changes, papillomatous projections, necrotic cells, infiltration of neutrophils and lymphocytes into stroma, pleomorphic cells, and infiltration of malignant squamous cells into deeper regions were also observed from the micrographic imaging (Fig. 5a-d).
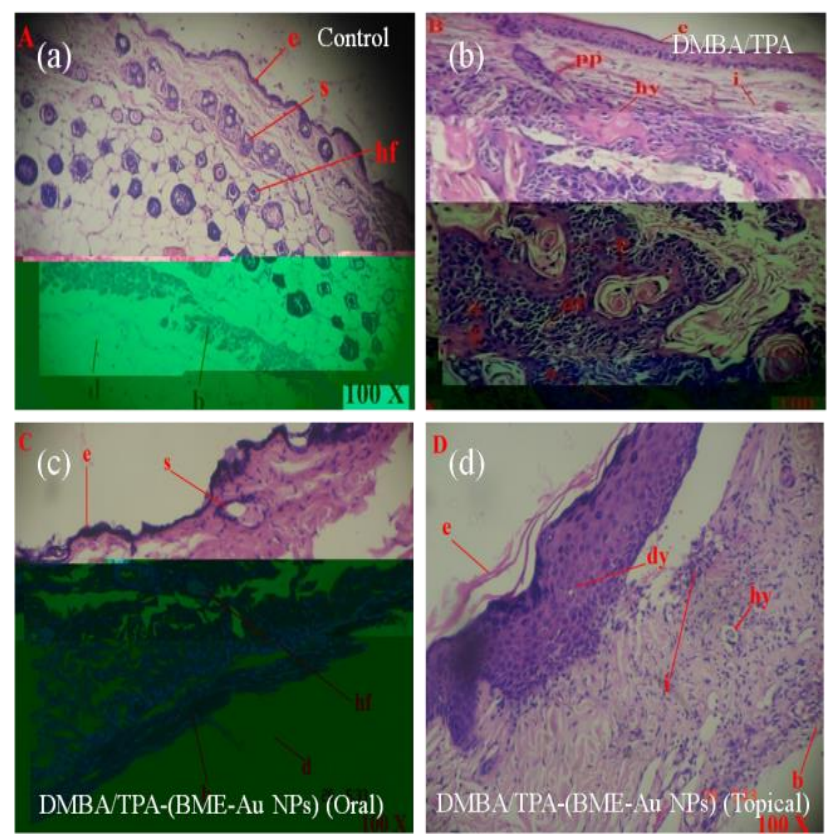

Fig. 5. Micrograph (a) shows histological section of normal/healthy skin in mice. Marks 'e' for epidermis, 'd' for dermis, 'b' for basal lamina, 's' for sebaceous glands, and ' $h f$ ' for hair follicles. Micrograph (b) shows histological section of DMBA/TPA induced skin tumor in mice ' $\mathrm{i}$ ' for infiltration of neutrophils and lymphocytes into stroma, ' $\mathrm{k}$ ' keratinocyte pearls, 'pp' for papillomatous projections, 'hy' for hyperkeratosis, 'df' for dermal fibrosis, and 'dy' for dysplastic epithelium. Micrograph (c) shows histological section of DMBA/TPA induced skin tumor in mice administered with BME orally as per the control group (a). Micrograph (d) shows histological section of DMBA/TPA induced skin tumor in mice administered with (BME-Au NPs) topically as per micrograph (b). Images were acquired at 100x magnification.

These changes suggest the characteristic feature of well differentiated squamous cell carcinoma. These pathological changes were completely prevented with the oral administration of BME. The extent of lesions developed in DMBA/TPA-BME (Topical) treated mice, were less as compared to DMBA/TPA treated group. Mild dysplasia, acanthosis and infiltration of malignant squamous cells into deeper regions were observed. From these results it seems that oral and topical administration of (BME-Au NPs) composite prevents the carcinogenesis significantly.

\section{Cell viability, inhibition assay and imaging}

To examine, the functionality of (BME-Au NPs) composite on cancer cells, three different cell lines such as cancerous K562 (leukemia blood cancer cells), HepG2 (hepatocellular carcinoma) and non-cancerous (HEK293, human embryonic kidney cell) were used for cell inhibition studies and cellular imaging [20, 23-25].

The (Fig. 6a), corresponds to cell viability with different concentrations (1.0, 5.0, 10, 25, 50 and $100 \mu \mathrm{g}$ $\mathrm{mL}^{-1}$ of (BME-Au NPs) composite and it demonstrates the less (negligible) effect on non-cancerous (HEK293) cells as the increase in concentration.

This composite is showing effect on cancerous cells [26-28]. The (Fig. 6b), illustrates the cellular inhibition with the above-mentioned concentrations of composite and inhibition is $>80 \%$ at $400 \mu \mathrm{g}$ of composite. The from the confocal microscopic imaging of K562 cells treated with developed nanoformulation (BME-Au NPs composite loaded with anticancer drug DOX), it is clearly evidenced that the morphology of cells was changed compared to untreated cells (Fig. 7a-d) [29-34].
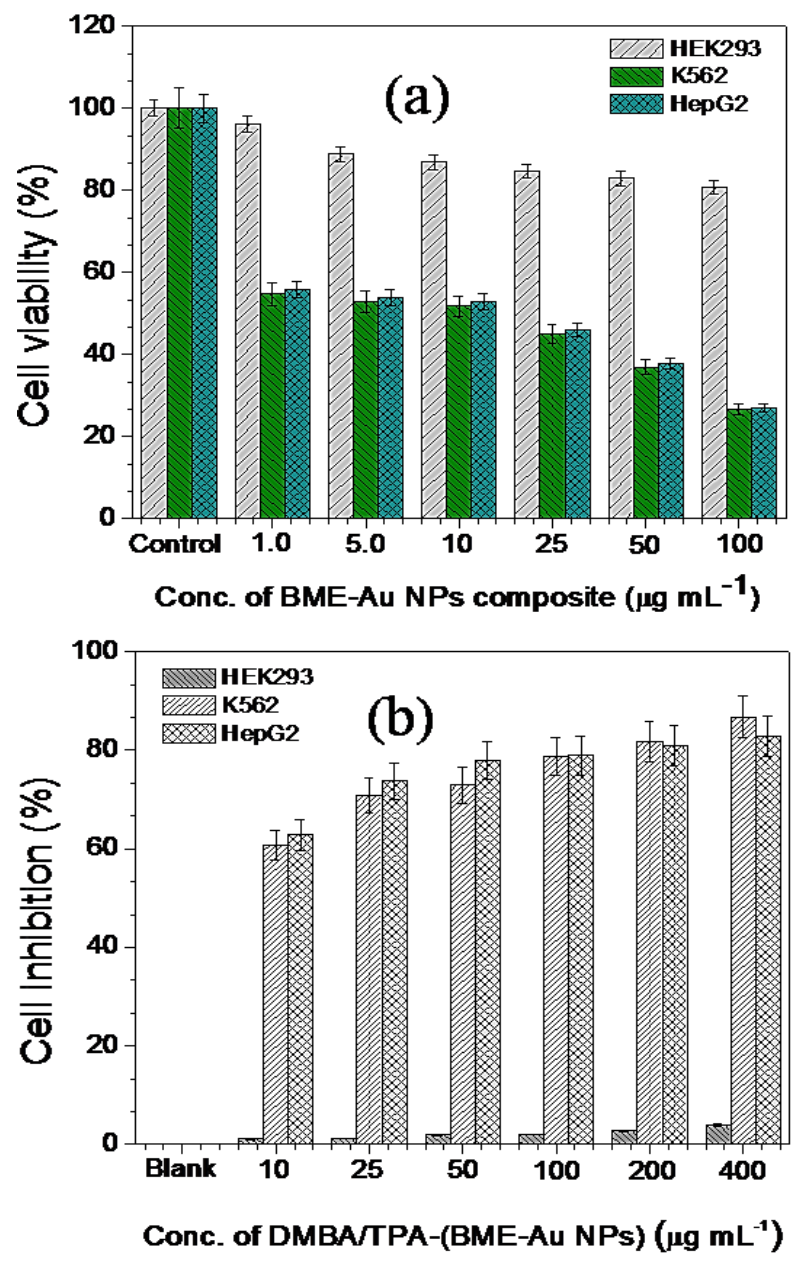

Fig. 6. The plot (a) corresponds to cell survival rate with composite of alcoholic plant extract (BME) and Au NPs. The plot (b) shows the cell inhibition on cancerous cells is more compare to noncancerous cells. 

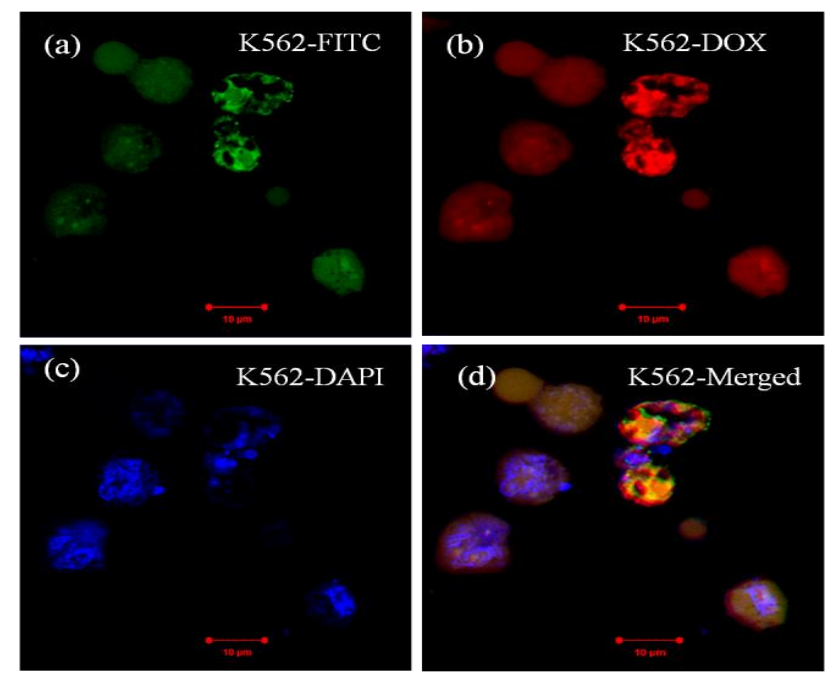

Fig. 7. Laser scanning confocal microscopic images of K562 cells. Cells were treated for $24 \mathrm{~h}$ with DMBA/TPA-(BME-Au NPs) fallowed by the incubation. Image (a) green fluorescent of K562 cells stained with FITC which stains cytoplasm, (b) red fluorescent images of cells stained with anticancer drug DOX molecules, (c) blue fluorescent stained with DAPI which stains A-T rich regions in the genetic material and $(d)$ corresponds to merged of $(\mathrm{a}, \mathrm{b}, \mathrm{c})$ cells.

\section{Conclusion}

In-vivo mice based results demonstrate the significant chemopreventive effect of (BME-Au NPs) composite on skin carcinoma cells upon oral and topical administration. It is found that significant reduction in tumor incidence, tumor burden, and tumor yield with (BME-Au NPs) composite. The cumulative number of tumors, tumor size, mass, volume, and LPO levels with a potential increase in the average latent period of tumor appearance, total protein, and DNA content is more evidenced for carcinogenic treatment on skin carcinoma. Composite is bio-safe and biocompatible to mankind without any side effects and cytotoxicity. It has been evaluated that (BME$\mathrm{Au}$ NPs) based composite shows decreased oxidative stress and prevents the DMBA induced TPA promoted skin carcinogenesis in mice. Furthermore, this BME-Au NPs composite has been used to treat leukemia blood cancer (K562) cells and it shows greater extent of cell inhibition. However, composite of (BME-Au NPs) can be used as a potential chemopreventive agent for skin carcinoma and to cure the several types of cancers and for other pharmaceutical applications.

\section{Acknowledgements}

Authors would like to acknowledge DST and UGC for financial support. The centre for nanotechnology can be acknowledged for TEM and EDAX facilities.

\section{Author's contributions}

The Collection of leaves and alcoholic plant extract and biological studies like tumor initiation and DNA content estimation has been performed by the Ramesh Gunti, Materials characterization and BMEAu NPs composite preparation and paper writing has been carried out by the Chander Amgoth, cell viability and inhibition studies were done by the Gangappa Dharmapuri and English language corrections and elemental analysis has been done by the Sumanjoshi Doddapaneni. Authors have no competing financial interests.

\section{Supporting information}

Supporting informations are available from VBRI Press.

\section{References}

1. Mertens,T. S.U.; Chintharlapalli, S.; Li, X.; Safe, S. Cancer Res. 2007, 67, 11001.

DOI:10.1158/0008-5472.CAN-07-2416.

2. Russ, H.; Bar, Y.; Ravassard, P.; Efrat, S. Diabetes. 2008, 57, 1575 .

3. DOI: $10.2337 / \mathrm{db} 07-1283$.

4. Collier, T.K.; Varanasi, U. Arch Environ Contam Toxicol. 1991, 20, 462.

5. Mubayi, A.; Chatterji. S,. Rai, P.M.; Watal, G. Adv Mater Lett. 2012, 3, 519 . DOI:10.5185/amlett.2012.icnano.353.

6. Yugandhar, P.; Haribabu, R.; Savithramma, N. 3 Biotech. 2015, 5, 1031.

DOI:10.1007/s13205-015-0307-4.

7. Polyak, K.; Kato, J.Y.; Solomon, M.J.; Sherr, C.J.; Massague, J.; Roberts, J.M.; Koff, A.Genes Dev. 1994, 8, 9.

8. Lu, M.; Chen, F.; Noy, J. M.; Lu, H.; Stenzel, M.H. Macromol Biosci. 2017. DOI: $10.1002 / \mathrm{mabi} .201600513$.

9. Kai, W.; Qida, H.; Wei, Z.; Mengmeng, Z.; Yuan, P.; Guping, T.Adv. Funct. Mater. 2015, 25, 3380.

10. Holm, R.; Weber, B.; Heller, P. Macromol Biosci. 2017. DOI: $10.1002 / \mathrm{mabi} .201600514$.

11. Fazal, S.; Jayasree, A.; Sasidharan, S.; Koyakutty, M.; Nair, S. V.; Menon, D. ACS Appl Mater Interfaces. 2014, 6, 8080. DOI: $10.1021 / \mathrm{am} 500302 \mathrm{t}$.

12. Sun, T.; Zhang, Y.S.; Pang, B.; Hyun, D.C.; Yang, M.; Xia, Y. Angew Chemie - Int Ed. 2014, 53, 12320. DOI: $10.1002 /$ anie.201403036.

13. Guiwen, W.; Carlos, H. J. Amer. Soc. Hort. Sci. 1995, $120,835$.

14. Kazuo, S.; Hiromi, O.; Sumiko, S.; Tatsuichiro, S.; Toshio, F. Analytical Biochemistry1983, 132, 345.

15. Randhawa, P.S.;Shapiro, R.; Jordan, M.L.;Starzl, T.E.; Demetris, A.J. Am J Surg Pathol. 1993, 17, 60.

16. Dong, Z. Mutat Res - Fundam Mol Mech Mutagen. 2003, 523, 145. DOI:10.1016/S0027-5107(02)00330-5.

17. Kawamori, T.; Lubet, R.; Steele, V.E. Cancer Research, 1999, 59, 597.

18. Kundu, J.K.; Surh, Y.J. Cancer Lett. 2008, 269, 243. DOI:10.1016/j.canlet.2008.03.057.

19. Goswami, S.K.; Das, D.K. Cancer Lett. 2009, $284,1$. DOI:10.1016/j.canlet.2009.01.041.

20. Fulda, S.; Debatin, K.M. Cancer Detect Prev. 2006, 30, 217. DOI: $10.1016 /$ j.cdp.2006.03.007.

21. Chander, A.; Gangappa, D.; Arunasree, M. K.; Pradip, P. Nanotechnology, 2016, 27, 125101.

22. Radi, R.; Freeman, B.A.; Beckman, J.S. Arch Biochem Biophys. 1991, 288, 481 . DOI: $10.1016 / 0003-9861(91) 90224-7$.

23. Dinis, T.C.; Maderia, V.M.; Almeida, L.M.Arch Biochem Biophys. 1994, 15, 161.

24. Sudip, M.; Bonda, R.R.; Bojja, Sreedhar.; Pradip, P.; Chitta, R.P. Chem. Commun., 2015, 51, 7325.

25. Liu, W.; Wen, S.; Shen, M.; Shi, X. New J Chem. 2014, 38, 3917. DOI: $10.1039 / \mathrm{C} 4 \mathrm{NJ} 00672 \mathrm{~K}$.

26. Ariga, K.; Ji, Q.; Mcshane, M.J. Chem Mater. 2012, 24, 728. DOI: $10.1021 / \mathrm{cm} 202281 \mathrm{~m}$.

27. Chen, J.; Zou, Y.; Deng, C.; Meng, F.; Zhang, J.; Zhong, Z. Chem Mater. 2016, 28, 8792.

DOI:10.1021/acs.chemmater.6b04404.

28. Mackiewicz, N.; Nicolas, J.; Handke, N. Chem Mater. 2014, 26, 1834. DOI: $10.1021 / \mathrm{cm} 403822 \mathrm{w}$.

29. Gao, W.; Shi, Y.; Zuo, L.; Fan, W.; Liu, T. Mater Today Chem. 2016, 1,32 . DOI: $10.1016 /$ j.mtchem.2016.10.003.

30. Shao, Y.; Shi, C.; Xu, G.; Guo, D.; Luo, J. ACS Appl Mater Interfaces. 2014, 6, 10381. DOI: $10.1021 / \mathrm{am} 501913 \mathrm{~m}$. 
31. Poon, Z.; Lee, J.B.; Morton, S.W.; Hammond, P.T. Nano Lett. 2011, 11, 2096.

DOI: $10.1021 / \mathrm{nl} 200636 \mathrm{r}$.

32. Yan, L. L.; Li, L.C.; Yan, M.; Feng, X. Ind. Eng. Chem. Res. 2013, 52,1571 .

33. Sahoo, B.; Devi, K.; Banerjee, R.; Maiti, T.; Pramanik, P.; Dhara, D. ACS Appl Mater Interfaces. 2013, 5, 3884.

34. Lee, H.J.; Bae, Y. Biomacromolecules. 2011, 12, 2686. DOI: $10.1021 / \mathrm{bm} 200483 \mathrm{t}$.

35. Li, F.; Danquah, M.; Mahato, R.I. Biomacromolecules. 2010, 11 , 2610.

DOI: $10.1021 / \mathrm{bm} 100561 \mathrm{v}$.

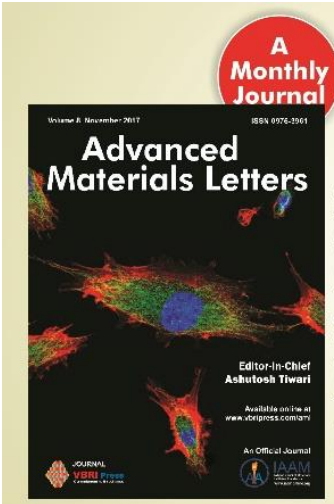

Copyright $\odot 2017$ VBRI Press AB, Sweden

\section{Publish}

\section{your article in this journal}

Advanced Materials Letters is an official internationa journal of International Association of Advanced Materials (IAAM, wwwiamonlineorg) published monthly by VBRI Press AB from Sweden. The journal is intended to provide high-quality peer-review articles in the fascinating field of materials science and technology particularly in the area of structure, synthesis and processing characterisation, advanced-state properties and applications of materials. All published articles are indexed in various databases and are available download for free. The manuscript management system is completely electronic and has fast and fair peer-review process. The journal includes review article, research. article, notes, letter to editor and short communications.

www.vbripress.com/aml 


\section{Supporting Information}

\section{Characterizations Techniques}

Following list of instruments were used to characterize the plant extract (BME), gold nanoparticles (Au NPs) and composite of (BME-Au NPs) and its chemopreventive studies in mice and on K562 cancer cells.

1) Auto analyzer (ERBA Chem-5 Plus V2) a clinical chemistry analyzer for extracts through the absorbance.

2) Binocular microscope (Nikon E200) to view the objects and imaging.

3) Digital electronic microbalance (Acculab).

4) Homogenizer (REMI, RQ 127A).

5) Micro centrifuge (Genei) for separation.

6) Micro-pipette (Accupipet).

7) $\mathrm{CO}_{2}$ incubator (Equitron, Medica Instrument) for cell culture and to treat the cell based samples by maintaining $5 \%$ volume of $\mathrm{CO}_{2}$ at $\sim 37^{\circ} \mathrm{C}$.

8) Sonicator (Ultrasonic cleaner, Enertech Electronics).

9) UV-Vis-NIR: Absorbance measurements were carried out using a Perkin Elmer (Lambda-750) model UV-Vis-NIR spectrometer. The calibration curve of absorbance against different concentrations of pure DOX was acquired at $530 \mathrm{~nm}$.

10) Multimode Reader: MTT assay, cell inhibition with DOX, imatinib and for the free DOX and imatinib were performed in 96 well plates using a BioTeck Synergy $\mathrm{H}^{4}$ multi mode reader.

11) LSCM: Fluorescence microscopy imaging experiments of the DOX molecules loaded micro and nanoporous polymeric capsules were performed by a Zeiss LSM 700 laser scanning confocal microscope. Micro and nanoporous polymeric capsules were incubated in DOX solution for $24 \mathrm{~h}$, then it was gently washed for thrice and re-dispersed in propanol and a drop of $(5 \mu \mathrm{L})$ dispersion was taken on a glass slide. After proper drying confocal microscopy images were acquired.

12) Sputter coating: The non-conducting natured polymer samples were sputter coated with metal ions (gold/Au) to get the conductivity throughout the surface of the polymer sample. The Quorum Q150R ES model sputter coating machine has been used for the same. The coating was carried out for 3 minutes with $10 \mathrm{~mA}$ of current. The density of the material is $19.32 \mathrm{~g} / \mathrm{m}^{3}$ with gold as sputtering material. The coating rate is $1 \mathrm{~nm} / \mathrm{min}$ and we obtained $\sim 3 \mathrm{~nm}$ thickness of gold ions on the surface of the polymer sample.

13) FESEM: Morphology and structure of porous polymeric capsules were observed with a Zeiss Ultra $^{\mathrm{TM}} 55$ field emission scanning electron microscope (FESEM) at $15 \mathrm{kV}$ accelerating voltage. Samples were coated with $\mathrm{Au} / \mathrm{Pd}$ on metal die.

14) EDAX (energy dispersive spectroscopy) has been used to analyze the elemental composition present in the composite of BME-Au NPs.

\section{Carcinogens and their handling}

The carcinogenic materials such as 7, 12diemthylbenz[a]anthracene (DMBA) and 12-Otetradecanolyphorbol-13-acetate (TPA) upon receipt from Sigma Aldrich suppliers were placed in a plastic freezer bag and stored in the freezer at $-20{ }^{\circ} \mathrm{C}$. A foil-wrapped scintillation vial and cap is weighed on an electronic microbalance and the weight has been noted. Then the vial is taken to the fume hood and a diaper is placed over the work area. Gloves and apron were worn during chemical transfer. A small amount of chemical is placed into the vial with a wooden applicator stick and replaced with the cap. The vial with the chemical is weighed and the quantity of chemical determined by subtraction method. Calculations performed to determine the amount of acetone to add to make a 10x stock solution and then to make a working solution. The stock and working solutions were stored in zip-lock bags in the freezer. Contact materials are disposed in the infectious/or biohazard waste. Unused solutions are arranged for proper disposal and incineration.

\section{Histological studies}

Histological changes in the skin were analyzed by the following procedure. Tumors and normal skin removed from sacrificed mice were immediately fixed in $10 \%$ formalin fixative for $24 \mathrm{~h}$. The tissue was then dehydrated in ascending series of alcohol and kept in mixture of absolute alcohol and benzene (1:1) and then in benzene for $1 \mathrm{~h}$ each. Finally, tissue pieces were embedded in paraffin wax and 4-micron thick sections were cut and spread on glass slides, stained with hematoxylin and eosin, slides mounted in DPX and viewed under optical microscope and fallowed by imaging. Globulins $=$ Total Protein - Albumin, Total protein concentration $(\mathrm{g} / \mathrm{L})=$ Total protein concentration $(\mathrm{g} / \mathrm{dL}) \times 10$. Total protein level in plasma is expressed as $(\mathrm{gm} / \mathrm{dL})$.

\section{The lipid peroxide level in plasma}

The following reagents are required for the measurement of lipid peroxide level in plasma such as $1.15 \mathrm{M}$ potassium chloride $(\mathrm{KCl})$, TBA reagent, and $0.25 \mathrm{M} \mathrm{HCl}$ containing $15 \%$ trichloroacetic acid, $0.375 \%$ of thiobarbituric acid and $0.055 \%$ of butylated hydroxy toluene and stored at $\sim 2-8^{\circ} \mathrm{C}$. The method involved in the estimation of bio-chemical parameters such as (1) $0.2 \mathrm{~mL}$ of plasma, $1 \mathrm{~mL}$ of $\mathrm{KCl}$ and $2 \mathrm{~mL}$ of chilled TBA reagent were added slowly with mild stirring and tubes were stoppered. The reaction mixture was then incubated at $\sim 80^{\circ} \mathrm{C}$ on a water bath for an hour, (2) the tubes were 
then cooled on ice bath for $5 \mathrm{~min}$ and centrifuged at 5000 RPM at $\sim 4^{\circ} \mathrm{C}$ for $10 \mathrm{~min}$ and (3) the absorbance of pink chromogen formed was measured against blank at excitation of $\sim 532 \quad \mathrm{~nm}$ with UV-Visible spectrophotometer.

\section{Different types of calculations}

The chemo-preventive potential of BME was accessed by considering the fallowing properties such as calculation of (1) survival time or (increase in life span), (2) change in body weight analysis, (3) cumulative number of tumors, (4) tumor incidence, (5) tumor burden, (6) tumor yield, (7) average latent period, (8) tumor size, tumor volume, and tumor mass. Based on final number of survival animals of DMBA/TPA tumor bearing mice, the average survival time (MST) and percentage of increase in life span (\% ILS) were calculated by using the equation (1) in table (1). Similarly, the body weight of mice before and after tumor induction was weighed with specific time intervals. The cumulative number of tumors in every week was measured till the end of experiment. The tumor incidence is defined as the number of mice carrying at least one tumor which is expressed as a percentage incidence and calculated by using the fallowing equation (2) in table (1). The tumor burden is defined as the average number of tumors per tumor bearing mouse, and it is calculated by using fallowing formula (3) in table (1). The tumor yield is defined as the average number of papillomas per mouse, and it is calculated by using fallowing formula (4) in table (1). However, the lag between the application of the promoting agent and the appearance of $50 \%$ of tumors has been determined. The average latent period was measured by multiplying the number of tumors appearing every week by the time in weeks after the application of the promoting agent and dividing the sum by total number of tumors. The average latent period has been calculated by using the fallowing formula (5) in table (1). The tumor size, shape, massand volume per mouse has been calculated through the digital Vernier calipers (Mitutoyo digimatic caliper IP 65 model). The diameter and radius (R) of each tumor was measured before and after the experiment to evaluate the tumor size, shape, volume and mass based properties.

$$
\begin{aligned}
& \text { 1) } \operatorname{ILS}(\%)=\frac{\text { MST of treated group-MST of control group }}{\text { MST of control group }} * 100 \ldots \text { (1) } \\
& \text { 2) Tumor incidence (TI) }=\frac{\text { No.of mice bearing tumors }}{\text { Total no.of mice }} \ldots \text { (2) } \\
& \text { 3) Tumor burden }(\mathrm{TB})=\frac{\text { Total no.of tumors }}{\text { Total no.of mice bearing tumors }} \ldots \text { (3) } \\
& \text { 4) } \text { Tumor yield (TY) }=\frac{\text { Total no.of tumors }}{\text { Total no.of mice }} \ldots \text { (4) } \\
& \text { 5) Average latent period }(\mathrm{ALP})=\frac{\sum \mathrm{fx}}{\mathrm{n}} \ldots \text { (5) } \\
& \text { 6) Tumor volume (TV) }=\frac{\mathrm{DR} 2 \pi}{6} \ldots(6) \\
& \text { 7) } \mathrm{MDA} / \text { Protein }(\mathrm{nmol} / \mathrm{mg})=\frac{\text { (O.D.)Test } \times \text { Total volume of reaction mixture }}{1.56 \times 10^{5} \times 10^{-9} \times \text { sample volume }} \times \frac{1}{\text { Protein }(\mathrm{mg} / \mathrm{mL})} \ldots \\
& \text { 8) Total protein concentration }(\mathrm{TPC}, \mathrm{g} / \mathrm{dL})=\frac{\text { Absorbance of test }}{\text { Absorbance of standard }} * 6.5 \ldots \text { (8) }
\end{aligned}
$$

Table. S1. Shows the equations and formula's involved in different calculations. The increase in life span, tumor incidence, tumor burden, tumor yield, average latent period, tumor volume and total protein concentration were calculated by using the above equations. 

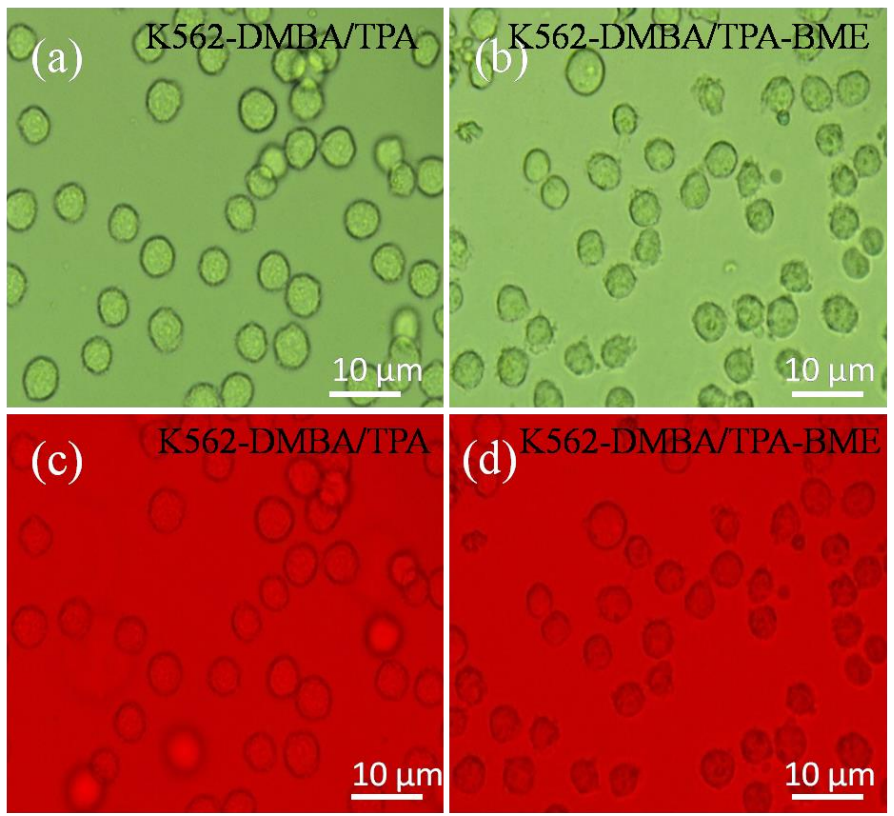

Fig. S1. Optical microscopic images of K562 (leukemia blood cancer) cells acquired before treatment with our BME-Au NPs based composite.

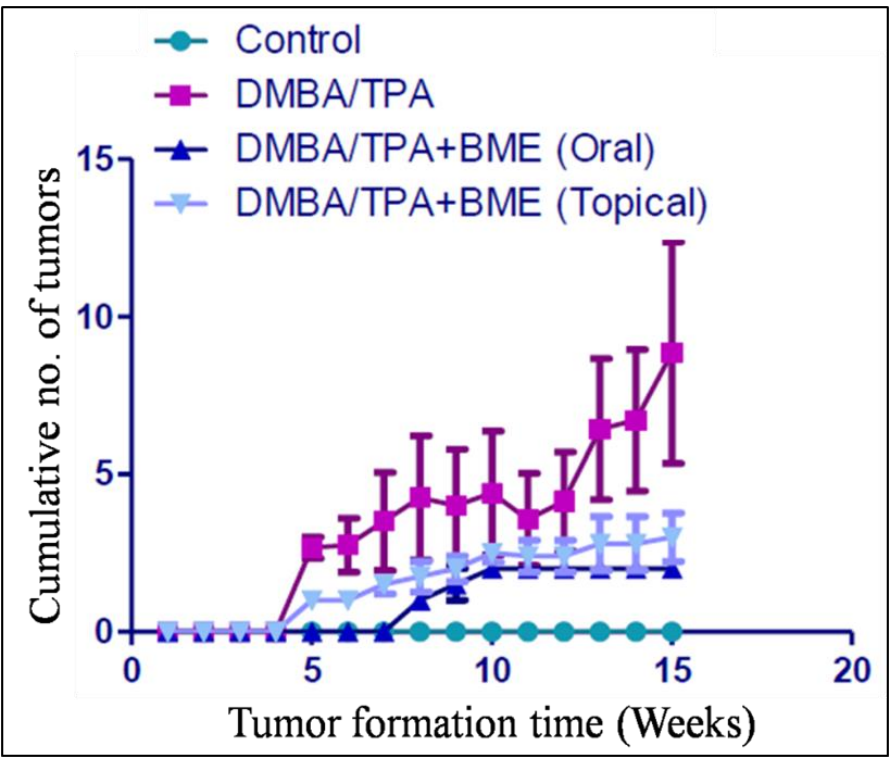

Fig. S2. Illustrates the increase in number of tumors with DMBA/TPA and their suppression with BME-Au NPs based composite

\begin{tabular}{|c|c|c|c|}
\hline Pipette into tube marked & Blank & Standard & Test \\
\hline Plasma & - & - & $10 \mu \mathrm{L}$ \\
\hline Reagent-1 & $1000 \mu \mathrm{L}$ & $1000 \mu \mathrm{L}$ & $1000 \mu \mathrm{L}$ \\
\hline Reagent-2 & - & $10 \mu \mathrm{L}$ & - \\
\hline
\end{tabular}

Table. S2. Represents the total protein working procedure. 


\begin{tabular}{|c|c|c|}
\hline Group & Status & Treatment methods \\
\hline $\mathbf{I}$ & $\begin{array}{l}\text { Normal control } \\
\quad(\mathbf{n}=10)\end{array}$ & Receives $100 \mu \mathrm{L}$ vehicles (acetone) topically twice in a week for 15 weeks. \\
\hline II & $\begin{array}{l}\text { Tumor control } \\
\qquad(\mathrm{n}=10)\end{array}$ & $\begin{array}{l}\text { Receives DMBA } 0.24 \% 200 \mu \mathrm{L} / \text { mouse topically for two applications in first week and } 5 \mathrm{nM} \\
\text { TPA } 50 \mu \mathrm{L} / \text { mouse twice in a week up to } 15 \text { weeks. }\end{array}$ \\
\hline III & $\begin{array}{l}\text { Tumor }+ \text { BME } \\
\text { (oral treatment) } \\
(\mathrm{n}=10)\end{array}$ & $\begin{array}{l}\text { Receives DMBA } 0.24 \% 200 \mu \mathrm{L} / \text { mouse topically, two applications in first week and } 5 \mathrm{nM} \text { TPA } \\
50 \mu \mathrm{l} / \mathrm{mouse} \text {, twice in a week from second week up to } 15 \text { weeks. These are treated with BME } 300 \\
\mathrm{mg} / \mathrm{kg} \text { (body weight, oral route). Thrice in a week before one hour of DMBA/TPA application. }\end{array}$ \\
\hline IV & $\begin{array}{l}\text { Tumor }+ \text { BME } \\
\text { (topical treatment) } \\
(n=10)\end{array}$ & $\begin{array}{c}\text { Receives DMBA } 0.24 \% 200 \mu \mathrm{L} / \text { mouse topically, two applications in first week and } 5 \mathrm{nM} \text { TPA } 50 \\
\mu \mathrm{L} / \text { mouse, twice in a week from second week up to } 15 \text { weeks. These are treated with BME } 300 \\
\text { mg/kg (body weight, topical route). Thrice in a week applied topically before one hour of } \\
\text { DMBA/TPAapplication. }\end{array}$ \\
\hline
\end{tabular}

Table. S3. Illustrate the experimental design and treatment methods fallowed by the dosages.

\begin{tabular}{|c|c|c|c|c|}
\hline \multicolumn{5}{|c|}{ Mean survival time (days) } \\
\hline S. NO & Control & DMBA/TPA & $\begin{array}{c}\text { DMBA/TPA-(BME-Au NPs) } \\
\text { (Oral) } \\
\end{array}$ & $\begin{array}{c}\text { DMBA/TPA-(BME-Au NPs) } \\
\text { (Topical) } \\
\end{array}$ \\
\hline $\mathbf{1}$ & 105 & 14 & 14 & 14 \\
\hline 2 & 105 & 14 & 14 & 28 \\
\hline 3 & 105 & 14 & 105 & 105 \\
\hline 4 & 105 & 105 & 105 & 105 \\
\hline 5 & 105 & 105 & 105 & 105 \\
\hline 6 & 105 & 105 & 105 & 105 \\
\hline 7 & 105 & 105 & 105 & 105 \\
\hline 8 & 105 & 105 & 105 & 105 \\
\hline 9 & 105 & 105 & 105 & 105 \\
\hline $\mathbf{1 0}$ & 105 & 105 & 105 & 105 \\
\hline $\begin{array}{l}\text { Mean } \\
\pm \text { SEM }\end{array}$ & $105 \pm 0.0$ & $77.70 \pm 13.90^{*}$ & $86.80 \pm 12.13$ & $88.20 \pm 11.25$ \\
\hline
\end{tabular}

Table. S4. Illustrate the effect of BME-Au NPs composite on mean survival time in mice exposed to DMBA/TPA oral and topical application. Data are expressed as Mean \pm S.E.M. $(\mathrm{n}=10)$. ${ }^{*} \mathrm{p}<0.05$ when compared to control sample. 


\begin{tabular}{|c|c|c|c|c|c|c|c|c|}
\hline \multicolumn{9}{|c|}{ Body weight (g) } \\
\hline \multirow[t]{2}{*}{ S. NO } & \multicolumn{2}{|c|}{ Control } & \multicolumn{2}{|c|}{ DMBA/TPA } & \multicolumn{2}{|c|}{$\begin{array}{c}\text { DMBA/TPA-(BME-Au NPs) } \\
\text { (Oral) } \\
\end{array}$} & \multicolumn{2}{|c|}{$\begin{array}{c}\text { DMBA/TPA-(BME-Au NPs) } \\
\text { (Topical) } \\
\end{array}$} \\
\hline & Initial & Final & Initial & Final & Initial & Final & Initial & Final \\
\hline 1 & 20.4 & 36.8 & 35.5 & 30.5 & 27.8 & $\longrightarrow$ & 26.3 & 34.9 \\
\hline 2 & 22.6 & 35.6 & 36.8 & 32.8 & 26.8 & 27.2 & 27 & 43.3 \\
\hline 3 & 29 & 41.8 & 32.6 & $\longrightarrow$ & 28.3 & $\longrightarrow$ & 31.8 & 30.7 \\
\hline 4 & 25.2 & 35.5 & 27.5 & 33.8 & 29 & 29.5 & 31 & 30.6 \\
\hline 5 & 27.3 & 40.5 & 28.4 & 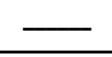 & 28.2 & 26.1 & 33.7 & 43.3 \\
\hline 6 & 26 & 26.3 & 30 & 35 & 28.7 & 32.9 & 20 & 22 \\
\hline 7 & 23 & 35.4 & 20.4 & 36.2 & 28 & 29.5 & 17.3 & $\longrightarrow$ \\
\hline 8 & 29.8 & 32.5 & 38.5 & 30.3 & 26.6 & 32.5 & 28.8 & $\longrightarrow$ \\
\hline 9 & 33.2 & 36.7 & 21.3 & 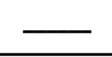 & 31.8 & — & 32.3 & 33.6 \\
\hline 10 & 31 & 41.1 & 19.8 & 38.1 & 31.4 & 29.1 & 32 & 30.9 \\
\hline Mean & 26.75 & 36.22 & 29.08 & 23.67 & 28.66 & 20.66 & 28.02 & 26.94 \\
\hline $\begin{array}{c} \pm \\
\text { SEM }\end{array}$ & 1.286 & 1.444 & 2.180 & $\begin{array}{c}* \\
5.219\end{array}$ & 0.5447 & 4.554 & 1.743 & 4.902 \\
\hline
\end{tabular}

Table. S5. Effect of BME-Au NPs composite on body weights of animals in mice exposed to DMBA/TPA topical application. Data are expressed as Mean \pm S.E.M. $(\mathrm{n}=10) .{ }^{*} \mathrm{p}<0.05$ when compared to control.

\begin{tabular}{|c|c|c|c|c|}
\hline \multicolumn{5}{|c|}{ Tumor burden } \\
\hline S. NO & Control & DMBA/TPA & $\begin{array}{c}\text { DMBA/TPA-(BME-Au NPs) } \\
\text { (Oral) }\end{array}$ & $\begin{array}{c}\text { DMBA/TPA-(BME-Au NPs) } \\
\text { (Topical) }\end{array}$ \\
\hline 1 & 0 & 9 & 2 & 6 \\
\hline 2 & 0 & 29 & 2 & 3 \\
\hline 3 & 0 & 6 & 0 & 2 \\
\hline 4 & 0 & 8 & 0 & 2 \\
\hline 5 & 0 & 6 & 0 & 2 \\
\hline 6 & 0 & 2 & 0 & 0 \\
\hline 7 & 0 & 2 & 0 & 0 \\
\hline 8 & 0 & - & - & - \\
\hline 9 & 0 & - & - & - \\
\hline 10 & 0 & - & - & $2.143 \pm 0.7693^{\#}$ \\
\hline Mean \pm & $0.0 \pm$ & $8.857 \pm$ & $0.5714 \pm 0.3689^{\#}$ & \\
SEM & 0.0 & $3.508^{*}$ & & 0 \\
\hline
\end{tabular}

Table. S6. Effect of BME-Au NPs composite on tumor burden in mice exposed to DMBA/TPA topical application. Date are expressed as Mean \pm S.E.M. $(\mathrm{n}=10) .{ }^{*} \mathrm{p}<0.05$ when compared to control and ${ }^{\#} \mathrm{p}<0.05$ when compared to DMBA/TPA treated group. 


\begin{tabular}{|c|c|c|c|c|}
\hline \multicolumn{5}{|c|}{ Tumoryield } \\
\hline S. No & Control & DMBA/TPA & $\begin{array}{c}\text { DMBA/TPA-(BME-Au NPs) } \\
\text { (Oral) }\end{array}$ & $\begin{array}{c}\text { DMBATPA-(BME-Au NPs) } \\
\text { (Topical) }\end{array}$ \\
\hline 1 & 0 & 9 & 2 & 6 \\
\hline 2 & 0 & 29 & 2 & 3 \\
\hline 3 & 0 & 6 & 0 & 2 \\
\hline 4 & 0 & 8 & 0 & 2 \\
\hline 5 & 0 & 6 & 0 & 2 \\
\hline 6 & 0 & 2 & 0 & 0 \\
\hline 7 & 0 & 2 & 0 & 0 \\
\hline 8 & 0 & - & - & - \\
\hline 9 & 0 & - & - & - \\
\hline 10 & 0 & - & - & $1.5 \pm 0.6191^{\#}$ \\
\hline Mean \pm SEM & $0.0 \pm 0.0$ & $6.2 \pm 2.752^{*}$ & $0.4 \pm 0.2667^{\#}$ & 0 \\
\hline
\end{tabular}

Table. S7. Effect of BME-Au NPs composite on tumor yield in mice exposed to DMBA/TPA topical application. Date are expressed as Mean \pm S.E.M. $(\mathrm{n}=10) .{ }^{*} \mathrm{p}<0.05$ when compared to control and ${ }^{\#} \mathrm{p}<0.05$ when compared to DMBA/TPA treated group.

\begin{tabular}{|c|c|c|c|c|}
\hline \multicolumn{5}{|c|}{ Average latent period (Weeks) } \\
\hline $\begin{array}{c}\text { No. of Weeks after TPA } \\
\text { Application }\end{array}$ & Control & DMBA/TPA & $\begin{array}{c}\text { DMBA/TPA-(BME-Au NPs) } \\
\text { (Oral) }\end{array}$ & $\begin{array}{c}\text { DMBA/TPA-(BME-Au NPs) } \\
\text { (Topical) }\end{array}$ \\
\hline 1 & $\mathbf{0}$ & $\mathbf{0}$ & $\mathbf{0}$ & $\mathbf{0}$ \\
\hline 2 & $\mathbf{0}$ & $\mathbf{0}$ & $\mathbf{0}$ & $\mathbf{0}$ \\
\hline 3 & $\mathbf{0}$ & $\mathbf{0}$ & $\mathbf{0}$ & $\mathbf{0}$ \\
\hline 4 & $\mathbf{0}$ & 1.333 & $\mathbf{0}$ & 2 \\
\hline 5 & $\mathbf{0}$ & 0.681 & $\mathbf{0}$ & 1.25 \\
\hline 6 & $\mathbf{0}$ & 1.285 & $\mathbf{0}$ & 1 \\
\hline 7 & $\mathbf{0}$ & 0.617 & 7 & 1 \\
\hline 8 & $\mathbf{0}$ & 0.4 & 3.999 & 1 \\
\hline 9 & $\mathbf{0}$ & 0.409 & 4.5 & 0.9 \\
\hline 10 & $\mathbf{0}$ & 0.4 & 4.5 & 0.833 \\
\hline 11 & $\mathbf{0}$ & 0.397 & 11 & $\mathbf{0}$ \\
\hline 12 & $\mathbf{0}$ & 0.710 & 12 & 1.714 \\
\hline 13 & $\mathbf{0}$ & 0.276 & 13 & $\mathbf{0}$ \\
\hline 14 & $\mathbf{0}$ & 0.846 & 14 & 0.933 \\
\hline Mean \pm SEM & $0.0 \pm 0.0$ & $\begin{array}{c}0.5253 \pm \\
0.1136^{* * *}\end{array}$ & $5 \pm 1.455^{\mathrm{BH}}$ & $0.7593 \pm 0.1786^{\#}$ \\
\hline
\end{tabular}

Table. S8. Effect of BME-Au NPs composite on average latency period in mice exposed to DMBA/TPA topical application. Data are expressed as Mean \pm S.E.M. $(\mathrm{n}=14)$. *** $\mathrm{p}<0.001$ when compared to control group, ${ }^{\#} \mathrm{p}<0.01$ and ${ }^{\#} \mathrm{p}<0.05$ when compared to DMBA/TPA treated group. 


\begin{tabular}{|c|c|c|c|c|}
\hline \multicolumn{5}{|c|}{ Tumor size (mm) } \\
\hline S. NO & Control & DMBA/TPA & $\begin{array}{c}\text { DMBA/TPA-(BME-Au NPs) } \\
\text { (Oral) }\end{array}$ & $\begin{array}{c}\text { DMBA/TPA-(BME-Au NPs) } \\
\text { (Topical) }\end{array}$ \\
\hline 1 & 0 & 3.655 & 1.8 & 2.701 \\
\hline 2 & 0 & 3.524 & 1.4 & 2.946 \\
\hline 3 & 0 & 3.220 & 0 & 2.97 \\
\hline 4 & 0 & 3.281 & 0 & 2.64 \\
\hline 5 & 0 & 3.630 & 0 & 2.22 \\
\hline 6 & 0 & 3.718 & 0 & 0 \\
\hline 7 & 0 & 3.505 & 0 & 0 \\
\hline 8 & 0 & - & - & - \\
\hline 9 & 0 & - & - & $1.685 \pm 0.4998^{\#}$ \\
\hline 10 & 0 & - & - & $0.2983^{\# \# \#}$ \\
\hline Mean \pm SEM & $0.0 \pm 0.0$ & $3.505 \pm$ & $0.4571 \pm 0$. & \\
\hline
\end{tabular}

Table. S9. Effect of BME-Au NPs composite on tumor size in mice exposed to DMBA/TPA topical application. Data are expressed as Mean \pm S.E.M. $(\mathrm{n}=10) .{ }^{* * *} \mathrm{p}<0.0001$ when compared to control, ${ }^{\# \#} \mathrm{p}<0.0001$, and ${ }^{\#} \mathrm{p}<0.05$ as compared to DMBA/TPA treated group.

\begin{tabular}{|c|c|c|c|c|}
\hline \multicolumn{5}{|c|}{ Tumor mass (mg) } \\
\hline S.NO & Control & DMВA/TPA & $\begin{array}{c}\text { DMBA/TPA-(BME-Au NPs) } \\
\text { (Oral) } \\
\end{array}$ & $\begin{array}{c}\text { DMBA/TPA-(BME-Au NPs) } \\
\text { (Topical) } \\
\end{array}$ \\
\hline 1 & $\mathbf{0}$ & 57.1 & 43.2 & 31.15 \\
\hline 2 & $\mathbf{0}$ & 61.25 & 37.03 & 34.37 \\
\hline 3 & $\mathbf{0}$ & 35.15 & $\mathbf{0}$ & 30.73 \\
\hline 4 & $\mathbf{0}$ & 41.93 & $\mathbf{0}$ & 34.25 \\
\hline 5 & $\mathbf{0}$ & 54.09 & $\mathbf{0}$ & 35.45 \\
\hline 6 & $\mathbf{0}$ & 40.58 & $\mathbf{0}$ & $\mathbf{0}$ \\
\hline 7 & $\mathbf{0}$ & 34.25 & $\mathbf{0}$ & $\mathbf{0}$ \\
\hline 8 & $\mathbf{0}$ & $\longrightarrow$ & $\longrightarrow$ & $\mathbf{0}$ \\
\hline 9 & $\mathbf{0}$ & - & - & - \\
\hline 10 & $\mathbf{0}$ & 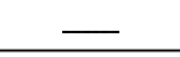 & 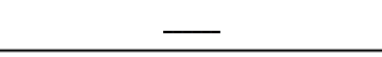 & 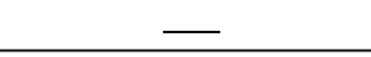 \\
\hline Mean \pm SEM & $0.0 \pm 0.0$ & $\begin{array}{c}46.34 \pm \\
4.147^{* * * *}\end{array}$ & $11.46 \pm 7.429^{\# \# \#}$ & $20.74 \pm 6.099^{\# \#}$ \\
\hline
\end{tabular}

Table. S10. Effect of BME-Au NPs composite on tumor mass in mice exposed to DMBA/TPA topical application. Data are expressed as Mean \pm S.E.M. $(\mathrm{n}=10) .{ }^{* * *} \mathrm{p}<0.0001$ when compared to control, ${ }^{\# \#} \mathrm{p}<0.001$ and ${ }^{\# \#} \mathrm{p}<0.01$ as compared to DMBA/TPA treated group. 


\begin{tabular}{|c|c|c|c|c|}
\hline \multicolumn{5}{|c|}{ Lipid peroxide in plasma (nM/mL) } \\
\hline S. NO & Control & DMBA/TPA & $\begin{array}{c}\text { DMBA/TPA-(BME-Au NPs) } \\
\text { (Oral) }\end{array}$ & $\begin{array}{c}\text { DMBA/TPA-(BME-Au NPs) } \\
\text { (Topical) }\end{array}$ \\
\hline 1 & 3.903 & 7 & 4.675 & 5.384 \\
\hline 2 & 2.423 & 5.384 & 4.576 & 3.153 \\
\hline 3 & 3.096 & 11.576 & 3.807 & 2.423 \\
\hline 4 & 5.115 & 6.076 & 5.807 & 5.115 \\
\hline 5 & 2.019 & 8.615 & 5.403 & 4.846 \\
\hline 6 & 0.538 & 2.288 & 3.467 & 2.153 \\
\hline 7 & 1.076 & 17.634 & 4.756 & 5.413 \\
\hline Mean \pm & $2.596 \pm$ & $8.368 \pm$ & $4.642 \pm 0.3099^{*}$ & $4.070 \pm 0.5445^{*}$ \\
SEM & 0.6018 & $1.885^{* *}$ & & \\
\hline
\end{tabular}

Table. S11. Effect of BME-Au NPs composite on lipid peroxides in plasma in mice exposed to DMBA/TPA application. Data are expressed as Mean \pm S.E.M. $(\mathrm{n}=7)$. ${ }^{*} \mathrm{p}<0.01$ when compared to control and ${ }^{*} \mathrm{p}<0.05$ when compared to DMBA/TPA treated group

\begin{tabular}{|c|c|c|c|c|}
\hline \multicolumn{6}{|c|}{ Total protein in plasma (g/dL) } \\
\hline S. NO & Control & DMBA/TPA & $\begin{array}{c}\text { DMBA/TPA-(BME-Au NPs) } \\
\text { (Oral) }\end{array}$ & $\begin{array}{c}\text { DMBA/TPA-(BME-Au NPs) } \\
\text { (Topical) }\end{array}$ \\
\hline 1 & 8.24 & 7.91 & 11.02 & 10.93 \\
\hline 2 & 7.51 & 8.66 & 8.83 & 7.42 \\
\hline 3 & 8.77 & 6.05 & 10.92 & 7.61 \\
\hline 4 & 8.16 & 5.65 & 8.85 & 7.38 \\
\hline 5 & 11.16 & 6.29 & 9.85 & 8.96 \\
\hline 6 & 8.7 & 7.06 & 8.10 & 8.08 \\
\hline 7 & 8.1 & 6.59 & 7.30 & 6.80 \\
\hline Mean \pm & $8.663 \pm$ & $6.887 \pm$ & $9.267 \pm 0.5287^{\# \#}$ & $8.169 \pm 0.5261^{\#}$ \\
SEM & $\mathbf{0 . 4 4 5 2}$ & $\mathbf{0 . 4 0 5 2 ^ { * * }}$ & & \\
\hline
\end{tabular}

Table. S12. Effect of BME-Au NPs composite on total protein levels in plasma $(\mathrm{mg} / \mathrm{mL})$ in mice exposed to DMBA/TPA topical application. Data are expressed as Mean \pm S.E.M. $(\mathrm{n}=7)$. ${ }^{* *} \mathrm{p}<0.01$ when compared to control, ${ }^{\#} \mathrm{p}<0.01$ and ${ }^{\#} \mathrm{p}<0.05$ when compared to DMBA/TPA treated group. 


\begin{tabular}{|c|c|c|c|c|}
\hline \multicolumn{5}{|c|}{ DNA content (mg/g of protein) } \\
\hline S. NO & Control & DMBA/TPA & $\begin{array}{c}\text { DMBA/TPA-(BME-Au NPs) } \\
\text { (Oral) }\end{array}$ & $\begin{array}{c}\text { DMBA/TPA-(BME-Au NPs) } \\
\text { (Topical) }\end{array}$ \\
\hline 1 & 0.788 & 0.187 & 0.889 & 0.962 \\
\hline 2 & 0.990 & 0.140 & 0.883 & 0.626 \\
\hline 3 & 0.670 & 0.355 & 1.548 & 0.665 \\
\hline 4 & 1.083 & 0.267 & 1.594 & 0.148 \\
\hline 5 & 0.804 & 0.634 & 1.093 & 1.084 \\
\hline Mean \pm & $0.8670 \pm$ & $0.3166 \pm$ & $1.201 \pm 0.1557^{\#+\# t}$ & $0.6970 \pm 0.1624^{*}$ \\
SEM & 0.07443 & $0.08737^{* * *}$ & & \\
\hline
\end{tabular}

Table. S13. Effect of BME-Au NPs composite on DNA content in skin tissue homogenate of mice exposed to DMBA/TPA topical application. Data are expressed as Mean \pm S.E.M. $(\mathrm{n}=5)$. ${ }^{* * *} \mathrm{p}<0.001$ when compared to control, ${ }^{\# \#} \mathrm{p}<0.001$ and ${ }^{\#} \mathrm{p}<0.05$ when compared to DMBA/TPA treated group. 